\title{
Abdominal mystery in a neonate
}

\section{Abdulrahman Halabi, ${ }^{1}$ Ubaidullah Khan, ${ }^{1}$ Kais Maazoun, ${ }^{2}$ Naglaa M Kamal (i) ${ }^{3}$}

A full-term male baby delivered at 38 weeks gestational age with birth weight of $3.3 \mathrm{~kg}$ was incidentally discovered soon after birth during routine nursery assessment to have abdominal distension with a soft mass felt in the upper middle part of abdomen measuring $10 \times 10 \mathrm{~cm}$. Other body system review revealed no abnormalities apart from bilateral undescended testes. Routine laboratory tests were within normal limits.

Only one antenatal ultrasound was done at 22 weeks gestational age with no significant abnormalities.

Radiological assessment by abdominal X-ray and abdominal ultrasonography (figure 1) was done.

\section{QUESTIONS}

1. What does the abdominal ultrasonography show?

A. Homogenous soft tissue mass.

B. Heterogeneous soft tissue mass with no calcifications.

C. Heterogeneous soft tissue mass with scattered fine calcifications.

D. Heterogeneous mass with soft, cystic and dense boney areas.

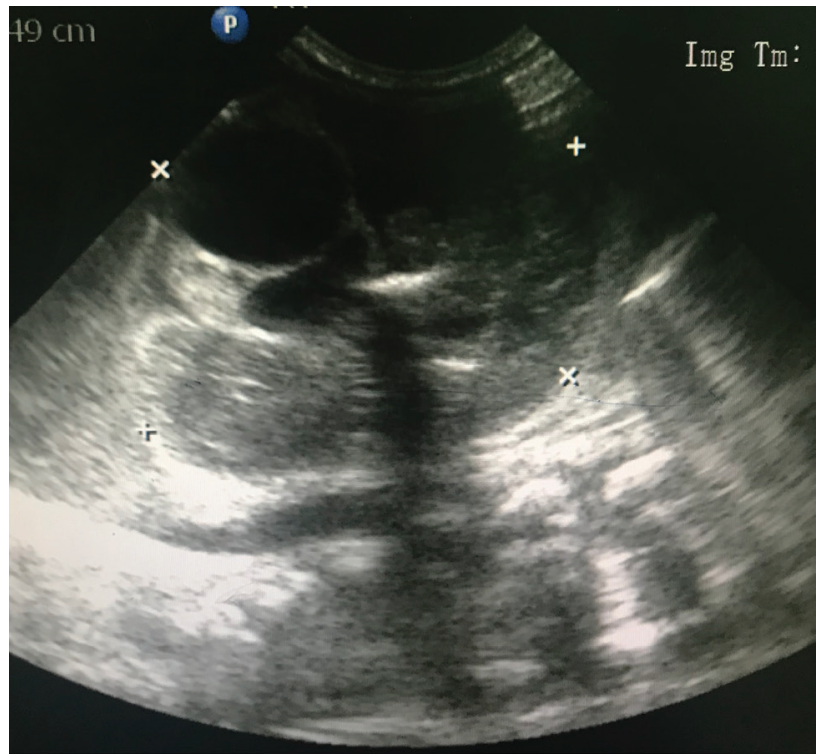

Figure 1 Abdominal ultrasonography showing a large abdominal mass containing bones and soft tissue.
2. Three-dimensional computed tomography (3DCT) of the abdomen (figure 2) was requested for better characterisation of the mass which revealed large encapsulated retroperitoneal soft tissue mass, $8.2 \times 5.5 \times 6.1 \mathrm{~cm}$ containing
A. Vertebrae.
B. Pelvic bones.
C. Long bones.
D. All of the above.
E. None of the above.

3. Following the 3D-CT, the following is the most appropriate laboratory test to be requested:
A. Alpha feto-protein.
B. Carcino-embryonic antigen.
C. Neuron-specific antigen.
D. $\beta$-human chorionic gonadotropin.
E. Vaniylmandilic acid-creatinine ratio.
F. All of the above.
G. A and D.

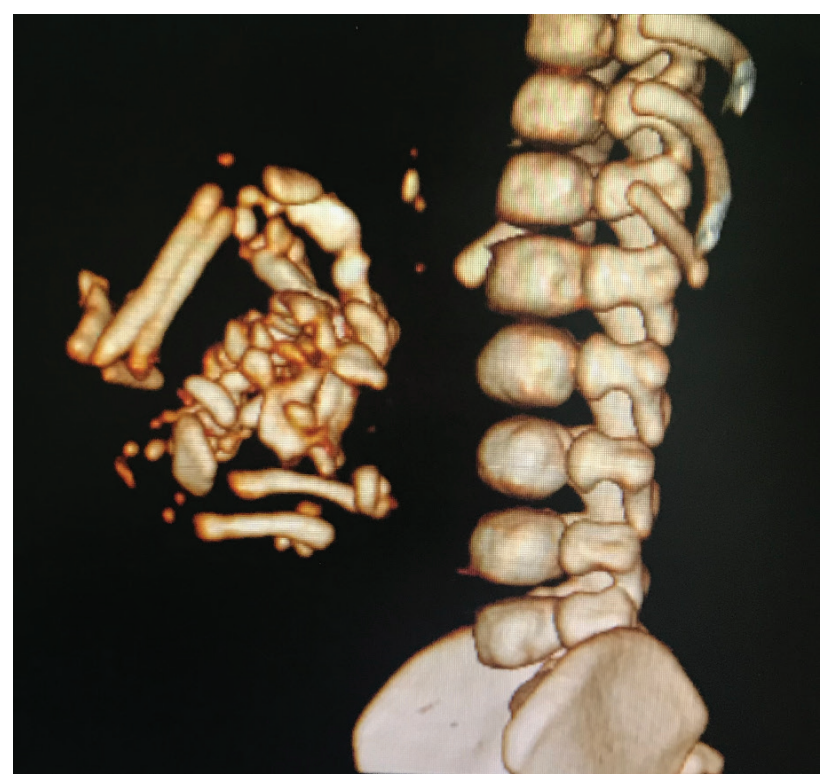

Figure 2 Three-dimensional reformats showed spatial relationship between child's lumbar spine and with visualized portion of the axial skeleton of the fetus in fetu. 


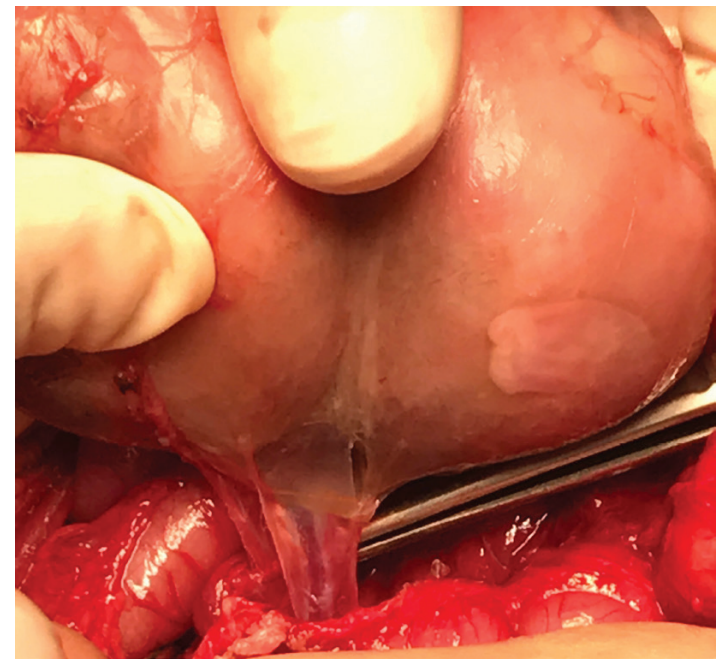

Figure 3 Retroperitoneal adherent to posterior structures, crossing vessel of mesentery which was saved and feeding vessel was lighted.

4. An elective laparotomy was performed which revealed a well-encapsulated, partially cystic retroperitoneal mass occupying most of the abdomen and displacing the left kidney, duodenum, liver and mesentery. A well-defined vascular pedicle was identified supplying the mass (figure 3). The mass was

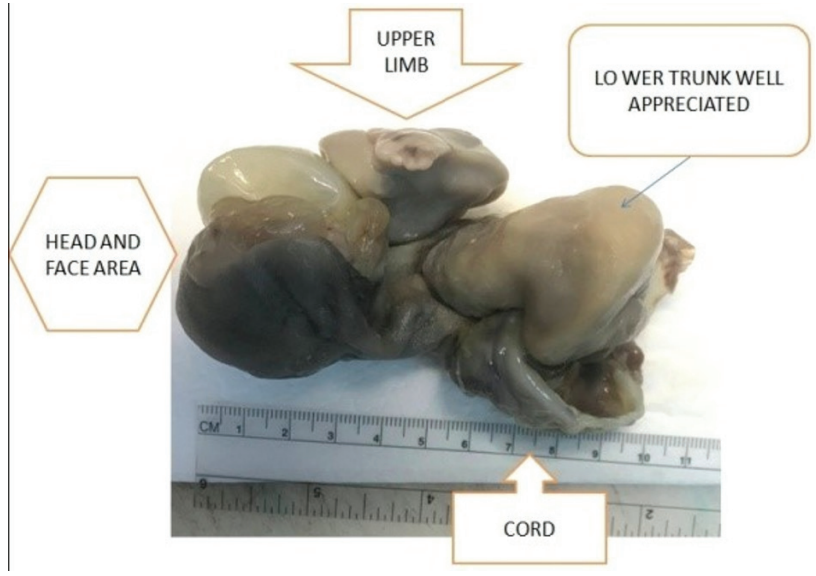

Figure 4 Fetu in fetus.

removed en bloc (figure 4). What is the most appropriate diagnosis?

A. Benign teratoma.

B. Malignant teratoma.

C. Neuroblastoma.

D. Wilm's tumour.

E. Fetus in fetu (FIF).

Answers can be found on page 229. 


\section{ANSWERS TO THE QUESTIONS ON PAGE 227}

\section{Question 1: the correct answer is D.}

The abdominal ultrasonography shows hypoechoic mass in left upper and middle abdominal region, measuring $8 \times 5 \mathrm{~cm}$, heterogeneous with soft, cystic and dense calcifications, mostly boney.

\section{Question 2: the correct answer is D.}

The mass contains multiple bones and soft tissue suggestive of limbs bones, pelvic bones, vertebral column and well-defined axial skeleton. The 3-D reformats showed fetal pelvis, lumbar spine and limb bones.

\section{Question 3: the correct answer is F.}

Teratoma is one of the differential diagnosis of the shown CT picture especially before surgical removal of the mass and because teratomas are malignant in $6 \%-10 \%$ of occasions, all the above-mentioned tumour markers should be done to exclude malignant possibility. They were all normal in our patient.

\section{Question 4: the correct answer is E.}

After removal of the mass, the gross picture was consistent with FIF with head with facial marks, axial skeleton, umbilical cord, both lower limbs with pincer like digital extensions, buttock and gentile mark, left upper limb with axial as well as digital extension and small right upper limb bud (figure 5). Cross section showed soft tissue, gut structures and axial bones.

FIF is a rare condition in which a malformed vertebrate fetus with organogenesis is found inside the body of its partner, usually in the abdominal cavity. It represents an anomaly of diamniotic, monochorionic,

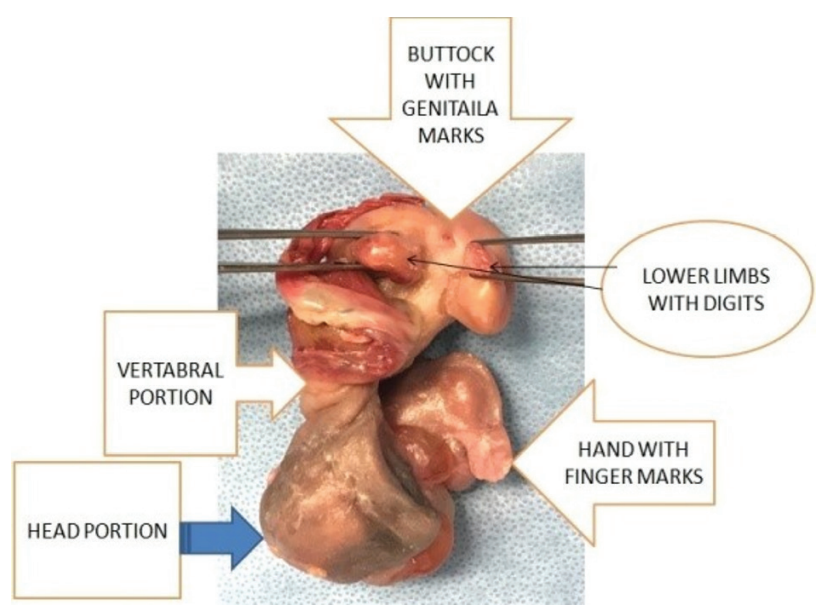

Figure 5 Complete gross pathology of the rudimentary fetus. monozygotic twinning in which unequal division of the totipotent inner cell mass of the developing blastocyst leads to the inclusion of a smaller cell mass within a maturing sister embryo.

FIF must have one or more of the following: (a) enclosed within a distinct sac, (b) covered by normal skin, (c) have grossly recognisable anatomic parts, (d) attached to the host by blood vessels and (e) either be located immediately adjacent to one of the sites of attachment of conjoint twins or be associated with the neural tube or the gastrointestinal system.

Our case fulfilled the criteria of FIF and teratoma is excluded as the mass has complete axial skeleton, vertebral part and large formed long bone of the limbs unlike teratomas which develop without the organisation.

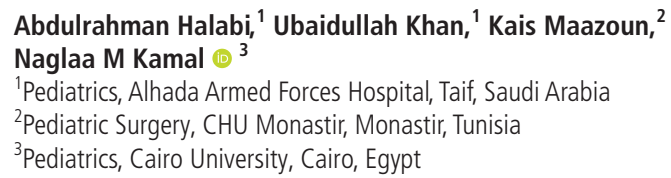

Correspondence to Dr Abdulrahman Halabi, Pediatrics, Alhada Armed Forces Hospital, Taif, Saudi Arabia; halabi03@yahoo.com

Contributors AH diagnosed the patient. UK and KM did the surgery. AH, UK and NMK wrote the draft. UK and NMK reviewed literature. All authors approved the manuscript for final publication.

Funding The authors have not declared a specific grant for this research from any funding agency in the public, commercial or not-for-profit sectors.

Competing interests None declared.

Provenance and peer review Not commissioned; externally peer reviewed.

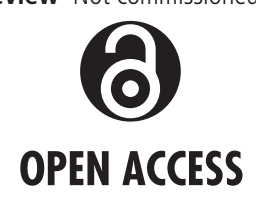

Open access This is an open access article distributed in accordance with the Creative Commons Attribution Non Commercial (CC BY-NC 4.0) license, which permits others to distribute, remix, adapt, build upon this work noncommercially, and license their derivative works on different terms, provided the original work is properly cited, appropriate credit is given, any changes made indicated, and the use is non-commercial. See: http://creativecommons.org/ licenses/by-nc/4.0/.

(C) Author(s) (or their employer(s)) 2020. Re-use permitted under CC BY-NC. No commercial re-use. See rights and permissions. Published by BMJ.

\section{Check for updates}

To cite Halabi A, Khan U, Maazoun K, et al. Arch Dis Child Educ Pract Ed 2020;105:227-229.

Received 13 September 2018

Accepted 15 December 2018

Published Online First 13 July 2019

Arch Dis Child Educ Pract Ed 2020;105:227-229. doi:10.1136/ archdischild-2018-316161

ORCID iD

Naglaa M Kamal http://orcid.org/0000-0002-8535-3838 